\title{
Effects of transportation on urban development: Sivrihisar, Turkey
}

\author{
E. Aksoy \& N. T. Gültekin \\ Department of City and Regional Planning, Gazi University, Turkey
}

\begin{abstract}
The junction, station and halting points of transportation connections are established with the development of settlements. This interaction between transportation and settlements has been a determining factor in social and economic development along with physical growth in the urban scale. In particular, regional transportation networks and transportation technologies, differentiated in parallel with transportation policies, direct urban development. This fact is relatively indicative of the trading activities within the city and its region. For this reason, the interaction between transportation and a city can basically be explained by "urban growth". This hypothesis will be examined in Sivrihisar in order to draw attention to some factors to be evaluated in the scope of provincial planning process.

Keywords: transportation, regional and local transit, urban transformation and form, urban development.
\end{abstract}

\section{Introduction}

In the history of civilisation, new settlements have been formed on transportation networks with the requirements of security, accommodation and exchange of goods. At the other end of the spectrum, existing settlements were improved or settlements were abandoned meaning that a transportation connection lost its economic importance. This mutual interaction between urban development and transportation can be observed with

- The transportation network, being indicative in urban macro-form and giving support to social and cultural development, and strengthening the economy.

- The inner and outer dynamics of the city, giving shape to the infrastructure and superstructure of transportation. 
This interaction that contains complex and many variables can be read on an urban scale with the physical characteristics and/or spatial structure together with the change and development of socio-economic and cultural structure. The interaction of urban development and transportation in Sivrihisar is examined within the historical process within this perspective. In this examination, the primary reasons for changing transportation connections on the regional and urban scales and their reflections in the city are investigated within a theoretical framework giving priority to the development process of transportation policies and technologies as the course of change.

\section{Effects of transportation on urban settlements}

In the mutual interaction of transportation and the city, there are some general factors, such as

- Change in the place and function of the city in the regional hierarchy; the effects of institutional structure on the city and as a corollary change in the function of the city in the urban hinterland.

- Spatial movements and change in the city centre and commercial activities with the change in regional transportation network, giving shape to the transportation system of the city,

- The dominant political structure that can be explained as the effects of, in particular, settlement and transportation policies on the shape and land-use of urban space [1].

There are a variety of theories and/or approaches on the effects of transportation in the city. These can be explained briefly as follows

- In the regional scale, more investment in transportation infrastructure forms the basis of regional development advantages.

- The settlement potential of the intersection points of two or more transportation modes is high.

- The most important effect of main transportation networks on settlements, having local economic and development potential, is their advantages in transportation possibilities.

- Transportation cost is a small part of the general production cost in industry. However, even if transportation cost is not a priority in the choice of a capital or a settlement, it is a secondary factor in the development of the economy.

- For maximum profit in transportation systems, it is necessary to operate different transportation modes in different scales, in harmony. Thus, city centre or urban services are located on the main transportation networks or on the intersection points.

- Theories that examine the relations between transportation and urban development aim for the optimal and equal use of land economy [2].

Thus, it can be said that the effects of transportation systems on cities can change according to the transportation networks on the urban and regional scales in addition to the transportation policies and technologies. 


\subsection{Effects of regional and urban transportation connections on the city}

Cities that have powerful and economic transportation connections on the national and regional scales attract not only local investments but global capital as well. The main transportation connections (railway networks, airports and ports etc) are indicative of the formation of local trade, business centres and the local economy. Furthermore, as it gives service to industry and business centres, it has a multiplier effect on an economic dimension. This effect, in urban settlements, supports both socio-economic and cultural development and + coincide with demographic changes and changes in economic status, land prices, choice of location of housing, and economic structure. So, the form of growth that characterises the city is based on the long-term balances that originate from the changes in the capacity of the transportation system [3]. Within this process, increasing inner city activity leads to problems originating from transportation. This is especially so in cities having a high population density. With the increase in private vehicle ownership, transportation infrastructure and urban infrastructure problems increase in unity [4]. Urban development is not only affected by the transportation modes. The development of road networks determines how land will be used. New roads lead to the opening of land that was previously not under pressure for urban growth [5]. Thus, the mutual interaction between form and transportation is continuously observed. In particular, in the dynamic periods of transportation history, there is much evidence of this interaction within the history of urban settlements. The initial effects of transportation characterize urban development in the 19th century. According to Barker, "this change appeared dramatically since the industrial revolution in developed countries as transportation was limited with the roads, railways and streetcars and human beings tended to settle around these lines" [6].

As of the end of the $19^{\text {th }}$ century, urban settlements have been constructed in the vicinity of urban routes and economic activities such as land prices and choice of industrial land are conclusively formed [6]. Within this process, smallscale cities grow and are formed by focusing on a mono-centered business district, where commercial activities dominate, generally located on the main transportation connections. The reason for the high land rent, building and usage density is that these centres have a high level of accessibility with strong transportation connections. Formations with sub-centres in relatively big cities, where there are mixed characteristics in land use without a definite separation between the usages such as trade, industry and housing, are also fed by transportation. Transportation policies connected with the developments in transportation and information and communication technologies also support the direction of cities to different attraction points with multi-central development. Contrary to this fact, in the globalisation process, urban space is transformed in a relation network into meeting the requirements of global capital [7]. In this process, with transition from fordist production to post-fordism, metamorphism in space continues. Thus, capital can spread production by dividing it into sections by using transportation possibilities. In other words, the identification of 
capital with flexible production relations that cannot be place-specific can be spread out over the whole of the world bounded to the transportation technologies and networks [8]. Thus, cities that have transportation possibilities developed technologically gain advantage with their changing spatial structure in integrating into the new world order.

\subsection{Effects of transportation policies on the city}

Transportation policies are aimed at meeting the demand of increasing goods and passenger transportation parallel to the development of economy and population. In meeting these demands, the organisation of transportation services and types of transformations in this organisation, are discussed with analyses. In these analyses, transportation services are used as an effective means in economic development together with meeting increasing transportation demands. So, transportation decisions that affect millions of human beings are taken [9].

Transportation policies are formed with technical analyses and technological development as much as with development scenarios in which politicians are used. In regional and urban scales, transportation routes, transportation mode, node and/or junctions, transfer points and thus settlement decisions in micro and macro scales, are determined together with transportation policies. Transportation policies can be variable as regards to different urban planning approaches. With an ecological approach, transportation policies offer more choice to human beings whilst the least damage is done to the environment. Not only cars but also other transportation modes such as bicycle, bus and train have been made attractive and transit systems have been made active. [9]. Thus, different transportation choices are empowered with computer technology and connection to different transportation modes. So it can be said that in the choice of transportation vehicles, transportation types and technological progress are also effective in changing the transportation policies.

\subsection{Effects of transportation technologies}

Technological developments in production, construction, travel, transportation and trade, have radically changed the functions and forms of urban centres and have strengthened suburbs to enlarge in the urban periphery [11]. The beginning of an extensive urban process with the factory system which appeared as a result of industrial revolution, led to an increase in different infrastructures in cities. However the transportation system, and in particular the car, spoilt this system and opened the way for people and industrial and commercial activities to be directed from urban centres towards the periphery. In connection with transportation technology, another factor that caused the city to spread out to the surrounding areas was the considerable investment given for access to the transportation network. This investment has increased the speed and compatibility of transportation in unit time. Thus, the new income originating from the decreasing transportation expenses has turned back to the economy for travelling to city centre, establishing business relations [10]. 
Information, telecommunication and transportation technologies also change urban form. This change began after the Second World War and it became dramatic in the 1950's. Autoway lanes and strengthened urban development placed agricultural areas under threat [12]. Within this process, it can be said that cities have been formed as centres where telecommunication and transportation technologies and means and information systems became dense. The effects of development continuing in these technologies, increased gradually after the second Industrial revolution. Currently, it can be said that globalisation has transformed the basic dimensions of societies with its investments and effects on the spatial form and dynamics of cities.

\section{Effect of transportation on urban development in the case of Sivrihisar}

The city of Sivrihisar was founded on the connection point of Western Anatolia to Eastern Anatolia in Phrygian period. Through the history, the city undertook one or many of the roles such as regional and transit trade, religious centre and logistic centre of military. Simultaneously the city, in the foundation period, became wealthy by the trading of agricultural products. Its location on the Royal Road provided this opportunity to the city [13-15]. In The Roman Period, (through the new road system and belief in a single god) Royal Road lost its importance [16]. In this period, Sivrihisar was on the Roman roads that connected the trade colonies. By realising that economic power determined by transportation was an effective weapon such as military power, administrators of the period developed the city and the new road network on which the city was founded. Seljuks accepted the policy of getting hold of trade in order to obtain this power and end the Byzantium domination. For this reason, they established guardhouse organisations for the security of trade and caravan (kervan) roads. In these organisations, new settlements were established on strategic points or development of the settlements near the caravan route like Sivrihisar was supported. So, the caravanserais (kervansaray) that were accommodation centres outside the cities became the focus of trade [17] thereby affecting the development of cities [18] within the vicinity. In this period development of Sivrihisar on the secondary caravan roads, was relatively slow.

\subsection{Urban change and development depending on transportation in the Ottoman period}

Road routes that Seljuks established in Anatolia changed in the Ottoman Period. The main caravan road interconnected with Istanbul passed through Sivrihisar. Thus, the city became a trade centre on a regional scale. The Ottomans also developed market opportunities for urban production with road security. Thus, from the $15^{\text {th }}$ century to the end of $16^{\text {th }}$ century, growth of Anatolian city continued with the establishment of new neighbourhoods outside the city walls. This fact is observed also in Sivrihisar with a population of 3500 in the end of $15^{\text {th }}$ century and 3750 in the beginning of $16^{\text {th }}$ century [19]. In the beginning of 
$16^{\text {th }}$ century inner factors like Celali riots, Great Kaçgun, "çift bozma" and exterior factors after the $18^{\text {th }}$ century caused structural changes in cities. Spatial structure of the cities and the balance that the urban population had reached in the beginning of 17 th century were preserved until the middle of $19^{\text {th }}$ century [20]. In this period the city developed as an important station point after the railway's establishment through Sivrihisar. However, connection of the railway to Eskişehir later, not only affected the socio-economic and cultural structure negatively but it also caused a transformation in spatial structure.

\subsubsection{Socio-economic indicators}

The Bursa-Tebriz Silk Road, which gained importance in the $15^{\text {th }}$ century [21] and the Aleppo, Damascus road, which crossed Anatolia diagonally [22] became determinative in the economic development of Anatolian cities. Sivrihisar was located in the middle of these transportation connections and became a trade centre in the regional scale in the $15^{\text {th }}-16^{\text {th }}$ centuries. "Bedesten", "kapan" inns "kapan han", caravanserai, bazaar, open markets (especially sheep bazaar) of this period were the indicators of development in trade [19].

Faroqhi states that there was a foundation "bedesten" with 36 shops and an inn, 68 foundation shops in Sivrihisar between 1550 and 1600. She also says that in this period there was cap, pistol, sadder, shoe manufacturers and a tannery. In the beginning of the $16^{\text {th }}$ century there were $400-1000$ tax-payers. Towards the end of the century the number reached to $1000-3000$ [17]. It is known that Eskişehir and its hinterland were affected by the Celali Riots that appeared with the distortion of economy in the $17^{\text {th }}$ century. However, there is no information in the written sources related to Sivrihisar's political history and economical life located in the hinterland of Eskişehir [13].

In the middle of the $19^{\text {th }}$ century the change in products also changed the transportation system due to the transfer of agricultural production to foreign trade as a result of the development in European industrial demand. Introduction of a railway to Anatolia, as a product of new transportation technology, was realised under these circumstances. In this process, crafts in cities collapsed as Western factory products took their place in the city markets as a result of the privileges provided to the European countries and trade capitalism developed in cities. In this period during which railways were effective in trade, Sivrihisar continued its importance in trade being a large market depending on its rural area. It is known that non-Muslims "gayr-i müslim" were wealthy in Sivrihisar. According to people of Sivrihisar who had experienced this period in the city, Crimean Tatars, who constitute the urban bourgeois, settled in the city and dealt with drapery, shoe-making and especially with the trade of agricultural equipment for the villages [13]. The Imperial edicts sent to Sivrihisar in the end of the $19^{\text {th }}$ century involved economy and trading issues and ordered the realisation of public requirements depending on transit trade [23]. The increasing number, variety and site of trade places continuing up to the current times were the indicators of economic development. 


\subsubsection{Socio-cultural indicators}

During massive migration to Anatolia after Russians invaded Crimea in 1783, immigrants were settled in the lands belonging to the state and foundations. Thus, not only new settlements were established, but new neighbourhoods were constructed around the cities and towns as well. In this period Crimean Tatars populated a new neighbourhood integrating the city from the east. So the population of Sivrihisar reached to 11200 in the 1800's [13]. After the Balkan War in 1880 the population migrating to Sivrihisar by using the HaydarpaşaAnkara railway passing through this region, reached to 34900 . With the changing trade system since the second half of the $19^{\text {th }}$ century, two basic classes appeared in the social stratification of Sivrihisar as in Anatolia.

- Greeks (in Turkish citizenship) tradesmen who became rich with foreign trade and Armanias collecting those tradable agricultural products from the villagers and dealing with wholesale trade on a small scale.

- Small tradesmen and craftsmen most of whom were Muslim Turks.

In the beginning of the $20^{\text {th }}$ century 4000 of urban population (36000) were non-Muslims. Size of the church explains that situation [23].

Muslims and non-Muslims living in Sivrihisar and emigrants had good neighbourhood relations with each other. They respected each other's life styles and even celebrated their special days together (bairam, marriage and death ceremonies and the like). In this period, non-Muslims accepted a western life style with the effect of Istanbul. However, this environment, ended after the nonMuslims left the city during the First World War and trade centre was transferred to Eskişehir through the railway [13].

\subsubsection{Physical-spatial structure}

The indicator of an Ottoman city is the "central mosque" (Cuma or Ulu Mosque) and "Bedesten" which is a semi-official and semi-public organisation [25]. The shopping district covers the entire centre. Public kitchens around "Bedesten" are gathered around different nuclei. There were business inns and caravanserais around the central nucleus [26]. The neighbourhoods were formed according to religious and ethnical identity rather than on the base of classes. "Ulu Cami" (Great Mosque) and a foundation "Bedesten" pertaining the Umur Beyoğlu Selçuk Bey with 36 shops, an inn and 102 foundation shops describe the Ottoman era city centre structure in Sivrihisar [17]. Organic settlement and transportation structure parallel to topography with a mosque as the central element in the Muslim neighbourhoods and church in the non-Muslim neighbourhoods, define the Ottoman era (Figure 1). As a result of the military class losing its power in the $17^{\text {th }}$ and $18^{\text {th }}$ centuries, the inner castle was left and senate houses (like the construction of Zaimoğlu House on the street very near the shopping centre) were located near the centre. This settlement structure could be seen in Anatolia until the $19^{\text {th }}$ century.

Change of socio-economic structure within the westernisation process, which was initiated by the effects of capitalism and industrial revolution in Europe, on the Ottoman Empire, was reflected on the spatial structure of cities. The dual 
structure appeared in central functions and in housing areas became the clearest aspect of Anatolian City towards the end of the $19^{\text {th }}$ century. In this period, in addition to the old centre that consisted of traditional trade on a local scale, a new centre was formed as the business centre by the trade bourgeoisie especially non-Muslims, who came to settle from abroad as a result of the changing foreign trade relations. This centre basically served the upper income group. In the housing areas, the immigrant neighbourhoods in grid-iron pattern near the organic pattern were the indicators of changing spatial structure. In the 1880's widespread use of horse drawn carriages for inner-city transportation, became effective in the formation of new neighbourhoods and big garden houses through the periphery [20] (Figure 2). In the area with a central church, where nonMuslims lived, the houses were attached near the centre and in gardens in the periphery. Even though it is not appropriate for topography, these neighbourhoods were designed in grid-iron pattern.

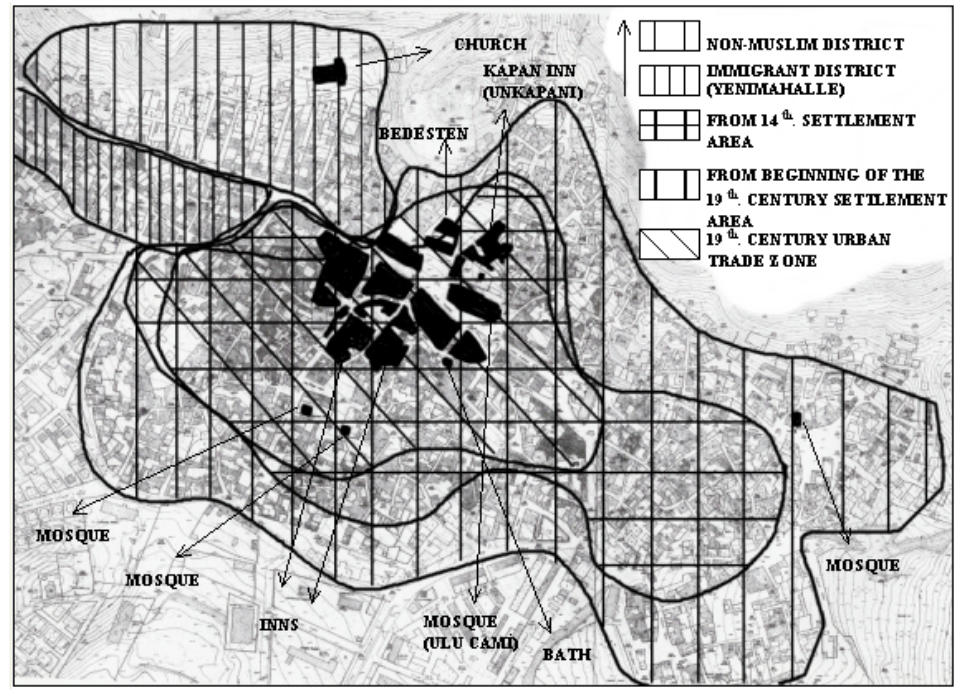

Figure 1: City center and housing area of Sivrihisar in the Ottoman era.

\subsection{Transportation and urban development interaction during the Republican era}

Due to the fact that the new government of the Republic preferred to supply regional investments in Eskişehir, Sivrihisar began to lose population and its economic power. Although, Sivrihisar was urbanized in the end of the $19^{\text {th }}$ century, with the effects of innovations in transportation technology, the city regained its rural character as a result of increasing importance given to roadway transportation instead of railways in the beginning of the $20^{\text {th }}$ century. 


\subsubsection{Socio-economic developments}

Due to the movement of non-Muslims from Sivrihisar and war economy, large shops, which were formerly managed by the non-Muslims were first transferred to the Muslims and were then closed. All shop owners who constituted most of the upper income group migrated to Eskişehir, which obtained the regional centre status. In the 1960s when the Ankara-Eskişehir road passed through the southern part of the city, regression of the city slowed down and, in particular, the location of Sivrihisar 1.5 kilometres from Afyon Eskişehir junction prevented the city from disappearing. Thus, it can be seen that regression of the city centre had become active as a result of the new regional transportation network. Meanwhile, the traditional trade centre has grown through the state highway on the south of the city.

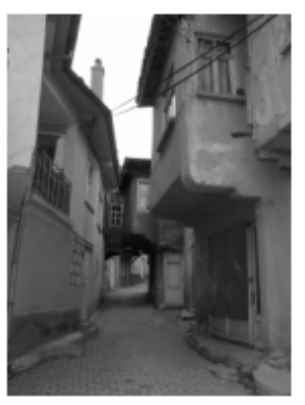

Figure 2:
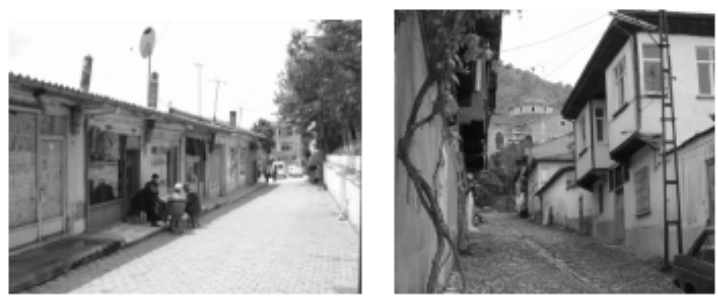

Traditional buildings of Sivrihisar.

\subsubsection{Socio-cultural developments}

In the beginning of the $20^{\text {th }}$ century, the city reduced in population and size. As a result of government policies giving greater importance to the highway network in Turkey in the 1950s a state road was built between Ankara and Eskişehir. In the same period, rural-urban migration accelerated movements from rural areas of Sivrihisar to Sivrihisar and big cities. Immigrants coming to rural areas settled in the houses abandoned by the non-Muslims and in immigrant neighbourhoods. This transformation caused the ruralization of the city.

\subsubsection{Physical-spatial structure}

The urbanisation process in Anatolia shows different characteristics to the urbanisation in industrialised countries. The first of these differences is insufficient development, especially in industrialization. However, unindustrialized cities have been affected enormously by the automobile, which was the product of industrial revolution, and so many important changes have appeared on the urban structure. In the Republican period during which this change could definitely be observed, urban life and land-use types changed radically. In rural areas with the development of state highways, car repairing shops, gas stations and restaurants were opened. Within this process, because of planning works in favour of road transportation, cities were faced with first demolitions and then transformations. The other factors are works of military 
institutions and their location in the land use, the opening of higher education institutions in some Anatolian cities and squatting. Recently, changes can be observed even in small settlements, which had preserved their stability. Because of land speculation former city centres have been changing characteristically by losing their original functions [27]. This process is active in Sivrihisar too and the city became smaller after the War of Independence. First the Non-Muslims left the city. After this movement, big shops in the city centre were first passed to the Muslims and then their capacities were diminished and finally they were closed. With the construction of new roads, Sivrihisar has found a place on the junctions of the communication networks of Western Anatolia. Even though the development plan, which was realised in 1970, stopped the growth of the city by increasing densities in the former trade centre, in 1980 the city was orientated towards the new state highway. In the 1990s new housing policies and the increasing intensity of the highway, led the housing areas to spread to the southern part of the highway.

\section{Conclusion}

The settlement potential of a location on primary and/or regional transportation networks or on the intersection point of one or more transportation mode(s) is as high in this century as in history. These types of settlement areas with high accessibility, gain the characteristic of being a centre in the regional hierarchy of trade. Settlements lose their economic competition power and/or their trading importance relatively with the change of long distance connections and/or transportation routes in the regional scale. This negative development is directly reflected on the urban settlement. Thus, planners, economists and urban politicians have to pay attention to the increase and differentiation of transportation needs parallel to economic development. Besides, with increasing transportation supply, local centres (secondary centres) within large central business districts also develop, and lead to the decentralization of urban settlements. However, knowledge of the relationship between transportation and urban development are rare along with limited analysis and experimental studies. This study is about the city of Sivrihisar by focusing on the effects of transportation on urban development.

\section{References}

[1] Aktüre, S., 16. Yüzyıl Öncesi Ankara'sı Üzerine Bilinenler, Tarih İçinde Ankara, Derleyen Ayşıl Tükel Yavuz, ODTÜ, Ankara, pp.3-48, 2000.

[2] Banister, D., Transport and Urban Development, Alexandrine Press, Oxford, pp.2-8, 1995.

[3] Marın, M.C., Altıntaş, H., Konut Yer Seçim-Ulaşım Etkileşim Teorileri: Kritik Bir Literatür İncelemesi, Gazi Üni. Müh. Mim Fak. Der., Ankara, Cilt 19, No 1, pp. 73-88, 2004. 
[4] Barter, P., A., Compact Cities: Sustainable Urban Forms for Developing Countries, Mike Jenks \& Rod Burgess, Spon Press, London, 279-281, 2000.

[5] Falleth, E. I., Suburban Growth and Land Actors along By-pass Roads in Norway, European Planning Studies, Vol. 7, No. 3, pp. 357-371, 1999.

[6] Araujo, J.,M., The Spanish Tramway As a Vehicle of Urban Shaping La Corunia 1903-1962, The Journal of Transport History, Vol. 26, 20-37, 2005.

[7] Tekeli, İ., Modernite Aşılırken Siyaset, İmge Kitapevi, Ankara, 1999.

[8] Harvey, D., Sosyal Adalet ve Şehir, Metis Yayınları, İstanbul, 2003.

[9] Sheehan, M., O., Choosing the Future of Transportation, The Futurist, pp. 50-56, July August 2001.

[10] Altıntaş, H., Dışsallıkların ve Teknolojik Gelişmelerin Dağınık Uzamsal Kent Gelişimindeki Rolleri ve Çevresel Bozulma, Gazi Üni. Sosyal Bil. Der., Ankara, Cilt 1, No 1, Mayıs 2004.

[11] Shapira, P., Urban Development, Journal of the American Planning Association, Winter97, Vol. 63, No. 1, 1997.

[12] Sinha, K., C., Sustainability and Urban Public Transportation, Journal of Transportation Engineering, pp. 331- 341, July August 2003.

[13] Gültekin, N., Özcan, Z., Çamur, K.,Ç., Dündar, Ö., Emür, S., H., Geleneksel Dokuda Kullanılabilirlik Ölçütlerinin Belirlenmesi Sivrihisar Geleneksel Konut ve Dokusu Örneği, Yaşanabilir Çevre Araştırma Dizisi1, Gazi Üni Araştırma Fonu, Ankara, 1998.

[14] Özalp, T., Sivrihisar Tarihi, Tacir Yayınevi, Eskişehir, 1960.

[15] “Ana Britannica”, Ana Yayıncılık A.Ş., İstanbul, pp. 443, 549, 1986.

[16] Owens, E. J., Yunan ve Roma Dünyasinda Kent, Cana Bilsel, Homer Kitapevi, İstanbul, pp. 115-116, 2000.

[17] Faroqhi, S., Osmanlı'da Kentler ve Kentliler Kent Mekanında Ticaret Zanaat ve Gıda Üretimi 1550-1650, Elif Kılıç, Türkiye Ekonomik ve Toplumsal Tarih Vakfi Yayınları, İstanbul, pp. 32-33, 61-75, 2000.

[18] Bektaş, C., Selçuklu Kervansarayları Korunmalarl, Kullanılmaları Üzerine Bir Öneri, Yap1-Endüstri Merkezi Yayınları, İstanbul, pp. 15-44, 1999.

[19] Doğru, H., XV. ve XVI. Yüzyılda Sivrihisar Nahiyesi, TTK, Ankara, 1997.

[20] Aktüre, S., 19. Yüzyll Sonunda Anadolu Kenti Mekansal Yapl Çözümlemesi, ODTU Mim. Fak. Basım, Ankara, pp. 74-90,135-140,195, 220-225, 1978.

[21] Busbecq, O., G., Türk Mektuplarl, Tekin Yayınevi, pp. 67-70, 1939.

[22] Andre-Asyan, H., D., Polonyall Simeon Seyahatnamesi 1608-1619, İstanbul Üniversitesi Edebiyat Fakültesi Yayınları, İstanbul, pp. 157-162, 1964.

[23] Özkaya, Y., Sivrihisar'ın 19. yy'daki Durumuna Genel Bakış, Tarihte Eskişehir Sempozyumu-1, Eskişehir, pp. 36, 2001.

[24] Işık, C., Şanlıer, K., Sosyo Ekonomik Gelişmede Eskişehir Nereden? Nereye?, Eskişehir Ticaret Odası Yayın, 2, Eskişehir, pp. 42, 69-70, 1988. 
566 Urban Transport XII: Urban Transport and the Environment in the 21st Century

[25] Karatepe, Ş., Kendini Kuran Şehir, Kültür Yayınları, Kayseri, pp. 25, 1999.

[26] Güçer, B., Anadolu Geleneksel Türk Kent Yerleşmesinde Konut-EkolojiÇevre İlişkisinin Araştırılması, (Basılmamış Yüksek Lisans Tezi), Gazi Üniversitesi, Fen Bilimleri Enstitüsü, Ankara, pp. 46, 1994.

[27] Aktüre, S., Osmanlı Devleti'nde Taşra Kentlerindeki Değişimler, Tanzimat'tan Cumhuriyete Türkiye Ansiklopedisi, İletişim Yayınları, İstanbul, pp. 28-29, 891-904, 1985. 